\title{
Technology Pedagogical Content Knowledge(TPCK) and Techno Pedagogy Integration Skill ( TPIS) Among Pre-Service Science Teachers- Case Study of a University Based ICT Based Teacher Education Curriculum
}

\author{
Dr Ajitha Nayar K \\ Indian Institute of Information Technology and Management Kerala, \\ Thiruvananthapuram,Kerala Pincode 695581, India \\ Sharifah Norul Akmar \\ Assoc. Prof . (Dr.), Department of Mathematics and Science Education, \\ Faculty of Education, University of Malaya, \\ Kuala Lumpur -50603. Telephone 60379675040
}

\section{The research is partly financed by University of Malaya Research Grant}

\section{Abstract}

The paper is an attempt to evaluate an effective Technology based Teacher Education course for Pre Service Science Teachers. The Technology in Science Education - a core course - is prescribed for an University based Pre-Service Science teachers Education program. The particular course is evaluated based on the TPACK framework which is an extension of the pedagogical content knowledge (Shulman,1986). The TPACK framework offers a viable and effective means for actual tryout of a Technology enabled Teacher Education Program. The volume of research that extruded from the TPCK/TPACK construct has provided deeper understanding of how teacher knowledge is related to pedagogical integration of digital technologies in educational contexts. As part of curricular transaction during the eleven week semester, the seven dimensions of TPACK viz., Technology Knowledge(TK), Content Knowledge (CK), Pedagogical Knowledge( PK), Technology Content Knowledge (TCK), Pedagogical content Knowledge (PCK), Technology Pedagogical Knowledge (TPK),TPACK (Technology pedagogical Content Knowledge) and an eighth dimension TechnoPedagogy Integration Skill ( TPIS) was evaluated with reference to the attainment of concepts and acquisition of skills. The effectiveness of the course was assessed by a Pre service Teacher's TPACK assessment inventory which comprised of an achievement test in Science which assessed pre service teachers attainment of science related concepts based on School level Science. The inventory comprised of a list of questions which pertain to the 7 dimensions as identified by the TPACK framework, The abbreviations and explanations are the same used by Mishra and Kohler( 2006). TechnoPedagogical Integration Skill (TPIS) was assessed by the assessment of teaching performance using technology before and after the course. Studies have reported that the implementation of TPACK framework has contributed to enhancement of Technological and Pedagogical concepts related to the subject (Hammond \& Manfra, 2009a; Khan, 2011; Manfra \& Hammond, 2008; Schul, 2010a, 2010b,Chai ,Koh and Tsai, 2013,Angeli \& Valanides, 2005; Bowers \& Stephens, 2011; Mishra \& Koehler, 2006; Tee \& Lee, 2011; Shafer, 2008). Similar attempts have been done earlier to assess the impact of TPACK using reliable and valid instruments (Schmidt However, the present study attempts to evaluate the effectiveness of a teacher preparation course with respect to technological and pedagogical skill acquisition and deployment for teaching science. Content Analysis of the course modules highlighted possibilities to draw parallels with the TPACK framework and it was thus that is was used as a frame of reference for the study.

Keywords: TPCK, University based ICT incorporated Teacher education curriculum, Pre service Science teachers DOI: $10.7176 / \mathrm{JEP} / 11-6-07$

Publication date: February $29^{\text {th }} 2020$

\subsection{Introduction}

Technology is making its presence felt in almost every facets of life more so in education. Technology- enabled learning environments have become important points of concern for education the world over. This has spearheaded a large volume of literature in classroom practices and teacher roles. It has become necessary for teachers to be accustomed to using technology in a variety of ways as technology has become an important resource for teachers and learners alike. Teacher Education Institutions (TEIs) become very important places in which to mould future teachers. TEIs are therefore faced with the challenge of preparing a new generation of teachers to effectively use the new learning tools in their teaching practices. For many teacher education programs, this daunting task requires the acquisition of new resources and expertise as well as careful planning (UNESCO,2012). To reap the full benefits of technology in learning, it is essential that pre service and in-service teachers have basic technology skills and competencies. Teacher education institutions and programmes must 
provide leadership for preservice and in-service teachers and model new pedagogies and tools for learning.

\subsection{Background of the study}

Studies have reported that the advent and adoption of new technologies have provided teachers with the opportunity to create dynamic, collaborative educational experiences for student learning (Martin \& Ertzberger, 2013; Wakefield \& Smith, 2012).Assessment of teacher's TPACK has received significant interest among researchers and different methodologies have been explored to conduct the assessment of teaching performance (Abbitt, 2011; Koehler,Shin,\& Mishra,2012, Harris, Grandgenett, and Hofer, 2012; Niess, Lee, Sadria, \& Suharwoto,2006).

Studies have revealed that lack of effective professional development targeting the pedagogical uses of computers in the Classroom is one of the most serious obstacles to integrating computers in the curriculum (Bos,2011; Falimi,1999; Grant,1996; Gess-Newsome,2001; Lieberman and Miller,1991; Little,1993, Schrum,1999). The skill based approach focus on teaching teachers how to use computer applications such as word processing, spreadsheets, email, internet and graphics. Skill based course are not enough for preparing teachers how to teach with computers, as they are usually taught in isolation from a pedagogical context (Becker and Reel, 2001; Selinger,2001). In the last decade the trend has been on subject specific computer applications. Teaching about technology use contributes to enhancement of TPACK(Hammond, T. C. \& Manfra, M. M., 2009; Archambault,2011; Haciomeroglu, E. S., Bu, L., Schoen, R. C., \& Hohenwarter, M.,2011). Every teacher professional development program should have a practical component during which teachers can actually teach with computers in their classrooms. These experiences will allow teachers to reflect on the feasibility of their designs as well as to situate their training in authentic contexts which is in the context of real classrooms (Bos 2011; de Olviera, J. M., 2010 ; Valanide and Angeli, 2008).

In this study apart from assessment of TPACK by means of achievement tests, Performance assessments is also attempted titled Techno pedagogical Integration Skill (TPIS).

A few teacher education programs have incorporated ICT based pedagogical courses for the undergraduate program with the objective of equipping prospective teachers in knowledge and skills related to Pedagogical use of technology in the classroom (Beck and Wynn,1998;Duhaney, 2001;Koehler \& Mishra, 2008,Wetzel and Zambo,1996; Young et al.,2000). It has been often observed that the primary reason for the discrepancy between the goals associated with appropriate technology consideration and current practice is a lack of teacher training (Brown, 2000; Lahm, 2005; Jackson, Ryndak, \& Billingsley, 2000; Okolo \& Bouck, 2007; Silver-Pacuilla, 2006).

\subsection{Methodology}

The study was conducted in a University based Teacher Education program in Malaysia. The particular course 'Technology in Science Education' was an elective course prescribed in the third year of the four year integrated Teacher education program. The objective of the course was to equip pre service teachers with ICT skills for teaching. Sixty pre-service teachers participated in the study. The group comprised of pre service teachers who had enrolled for various undergraduate programs in Education viz., Technology in Science Education. Students had the option to complete the course within 4 years of the integrated teacher preparation program in ICT . For the year under research 20 students had opted for the course. The duration of course covered 14 weeks. The classroom for conduct of the class and subsequent research were technology enabled classrooms with one computer per student. All computers had net connectivity facilitating conducive techno-pedagogical interventions.

\subsubsection{Description of the course}

The Teacher education curriculum comprise of two core courses and two electives. The ICT inbuilt course Technology in science education is a course which in a way imbibes and adopts the TPACK in theory as well as practice. The study evaluated the effectiveness of a particular course Technology in Science Education. in TPACK by assessing pre service teachers Techno Pedagogical integrated skill (TPIS) through performance based criteria and assessments over a 10 weeks excluding weeks for Pre testing and Post testing .

The Pre test for teaching was done in the first week and pre testing for all components corresponding to TPACK was done before the commencement of the particular module. The post testing for each component was done on the subsequent week of completing the module to maintain parity with regard to elapsed time of content delivery for each component. The component based concepts which were dealt in each week are given in Table 1 and the courses in Table 2

\subsubsection{Description of tools}

Achievement test for assessing-Technology knowledge (TK)

The TK comprised of 10 questions pertaining to fundamentals of computer. The Achievement test prepared by a team of experts with a maximum score of 20 marks was administered by online survey mode. The online test was administered both before (Pre test) and after the module session (Post test). The link to the survey was opened 5 minutes prior to administering and was closed after 15 minutes before onset of Pre test session and post test sessions. The mean pre test and post test achievement scores were compared to assess the effectiveness of the 
curricular intervention with regard to attainment of concepts related to technology.

Assignment - for assessing-Pedagogical knowledge (PK)

The assignment comprised of a brief write up on any particular theory of learning and how it accepts or contributes to technology based pedagogies. One week was given for submission of assignment. The Assignment was assessed by external raters who were teacher practitioners based on a scale which rated 5 criteria - literature reviewed, content and explanations, analysis and interpretation, justifications given in conclusion and rightness of data seminar- for assessing-Technology Pedagogical knowledge (TPK)

The group seminar topic was assigned to the student before the onset of the particular module. The groups were assigned by random selection. Four members comprised a group. Three weeks were given for seminar presentation. The topic assigned pertained to the theme 'Using technology for pedagogy - case study of an technology based Instructional strategy'. The topic thus was common as well as different with regard to the case study. The presentation was rated by participant group, peer group and researcher based on the criteria -The rating scale was assessed by external raters who were teacher practitioners. The scale rated 5 criteria -suitability, feasibility, practicability, association between technology and pedagogy, scope for enhancing affective variables -motivation, arousing curiosity, opportunities for student engagement, opportunities for student exploration, collaboration and networking. The average of the ratings were taken as the mean score for each group. The total mean scores obtained for TCK was compared between the groups and the tests of significance was computed using Analysis of variance Skill assessment - for assessing-Technology Content knowledge (TCK)

The Technology content knowledge was assessed by a rating scale before and after the introduction of the concerned module. The task given was identification and collection of appropriate e-resources for teaching a particular science concept. The rating scale was assessed by external raters who were teacher practitioners. The scale rated 5 criteria -suitability, feasibility ,practicability, divers ability and multimedia inclusivity TPIS

The TechnoPedagogical Integration skills (TPIS) is actually the practical implementation of TPACK. TPACK refers to the cognitive domain centered around the attainment of concepts, developing understanding, generating and consolidating knowledge. However, the skill is not implied. Teaching has been described as a skill, the deploying of which becomes an action which in turn reflects a practical approach to a theory. Thus one could infer that TIPS is TPACK in action or the practice of TPACK. Needless to add teaching is a performance therefore performance based assessment was done in the last phase to evaluate the effectiveness of the course with regard to development of TPACK and acquiring skills in TPIS

The tool used to estimate TPIS score was an observation schedule cum performance portfolio. The TPIS score was an assessment of actual teaching skills - action based on TPACK or performance group seminar topic was assigned to the student before the onset of the particular module. The pre-test TPIS score and the post test TIPS score. The observation schedule helped in recording observations and enumerating frequencies of positive teacher behavior and bad teacher behavior. TPIS being an integrated concept was assessed at the beginning of the course to avoid the influence of any intervening variable and was referred to as Pre TPIS score.

The Flanders's Interaction Analysis Category system (FIACS) formed the basis in identifying positive and negative teacher behavior. Every time a good teacher behavior is observed the observee gets a 2 and each time a negative behavior is observed the observee gets a zero. observation is a form of continuous assessment The performance based assessment used for assessing teacher behavior rated 6 criteria on a 1-5 scale viz., time management, class management, control of technology, familiarity with e-resource, level of confidence in using technology for teaching and the level of competency in subject knowledge.Performance based assessment was a summative assessment as it rated overall teacher behavior. The total of positive and negative scores for observations gave the mean observation score (TPIS1). The total of ratings gave mean rating score for performance (TPIS2). The total of TPIS1+TPIS2 gave overall mean score for TPIS.

\subsubsection{Experimental procedure}

The study intended to evaluate the Technology in Science Education based on the components of TPACK- viz., the Technological, Pedagogical and Content knowledge of pre service teachers enrolled for a four year undergraduate pre service teacher education program. The researcher taught the particular course - viz., Technology in Science Education for the prescribed period of 4 months. Before commencement of the course the pre tests were conducted for all the components of TPACK (See Appendix 2). The course had 5 Units- Introduction to computers, Unit ii- Theories of Technology based Instructional strategies Unit iii Introduction to search engines and locating suitable sites related to Science. Unit iv software application software and its pedagogical applications. After the course the post tests were conducted. The pre test mean scores and the post test mean scores were compared with regard to - CK, PK, TK, TPK, TCK, TPK and TPCK. The significance of difference between means were calculated using tests of variance. 
Table 1: Domains, Component based concepts and Learning Outcomes

\begin{tabular}{|c|c|c|c|}
\hline Week & Domains & Details of course content & Learning outcome \\
\hline Week 1 & \multicolumn{3}{|l|}{ PRETESTING } \\
\hline Week 2 & $\begin{array}{l}\text { Cognitive }- \\
\text { lower order- }\end{array}$ & $\begin{array}{l}\text { Concept of science } \\
\text { technology based instructional strategies and } \\
\text { familiarity of technology based instructional } \\
\text { strategies, e- resources for information } \\
\text { collection, comprehension }\end{array}$ & $\begin{array}{l}\text { Subject Content } \\
\text { Awareness test } \\
\text { (CK) }\end{array}$ \\
\hline Week 3 & $\begin{array}{l}\text { Higher order } \\
\text { thinking } \\
\text { skills- }\end{array}$ & $\begin{array}{l}\text { attainment regarding theoretical foundations of } \\
\text { learning developing of competency in } \\
\text { pedagogical basis of content delivery, }\end{array}$ & $\begin{array}{lr}\text { Subject } & \text { content } \\
\text { Achievement } & \text { test(PK) } \\
\text { PCK } & \end{array}$ \\
\hline Week 4 & Psychomotor & $\begin{array}{l}\text { Design and preparation of technology based } \\
\text { instructional material for content delivery }\end{array}$ & $\begin{array}{l}\text { Content based } \text { Skill } \\
\text { assessment (TPK) }\end{array}$ \\
\hline Week 5 & Affective- & $\begin{array}{l}\text { Aesthetic sense displayed in presentation of the } \\
\text { selected content, consideration given to sustain } \\
\text { interest in topic and motivate the students }\end{array}$ & $\begin{array}{lr}\text { Evaluation } & \text { of } \\
\text { instructional } & \text { resource } \\
\text { developed } & \end{array}$ \\
\hline Week 6 & $\begin{array}{l}\text { Technology } \\
\text { Cognitive }- \\
\text { lower order- }\end{array}$ & $\begin{array}{l}\text { Understanding of technology and fundamental } \\
\text { concepts related to technology Familiarity of } \\
\text { hardware and software components of } \\
\text { computer/regarding }\end{array}$ & $\begin{array}{l}\text { Technology Awareness } \\
\text { test (TK) }\end{array}$ \\
\hline Week 7 & $\begin{array}{l}\text { Technology - } \\
\text { Psychomotor- } \\
\text { Lower order - }\end{array}$ & $\begin{array}{l}\text { selection of suitable e-resource and e-application } \\
\text { for developing technology based instructional } \\
\text { resources, selection of suitable ICT based } \\
\text { pedagogical application for content delivery, }\end{array}$ & $\begin{array}{l}\text { Technology based skill } \\
\text { assessment -Skill based } \\
\text { assessment } \\
\text { data gathering skills, } \\
\text { (TPK), }\end{array}$ \\
\hline Week 8 & $\begin{array}{l}\text { Technology - } \\
\text { Psychomotor- } \\
\text { Higher order - }\end{array}$ & $\begin{array}{l}\text { selection of suitable e-resource and e-application } \\
\text { for developing technology based instructional } \\
\text { resources, }\end{array}$ & \\
\hline Week 9 & $\begin{array}{l}\text { Technology - } \\
\text { Psychomotor- } \\
\text { Higher order - }\end{array}$ & $\begin{array}{l}\text { selection of suitable ICT based pedagogical } \\
\text { application for content delivery, Organization } \\
\text { and consolidation of content, tapping potentials } \\
\text { for Networking and collaboration }\end{array}$ & $\begin{array}{l}\text { Technology based skill } \\
\text { assessment -information } \\
\text { processing skills } \\
\text { networking and } \\
\text { collaborative skills } \\
\text { (TPCK) }\end{array}$ \\
\hline $\begin{array}{l}\text { Week } \\
10\end{array}$ & Pedagogical & $\begin{array}{l}\text { introduction of content, Management of } \\
\text { resource in the classroom, content presentation, } \\
\text { interaction with students, assessment of } \\
\text { students, }\end{array}$ & $\begin{array}{l}\text { Performance based } \\
\text { assessment } \\
\text { Test(Technology } \\
\text { Pedagogy Integration } \\
\text { skill)(TPIS) }\end{array}$ \\
\hline
\end{tabular}

Effective ICT practices imply transfer of ICT skills to students through deployment of ICT skills by teachers. Here, the students are a group of 20 pre service teachers. The most desirable of ICT skills that are required and needed for the digital learning community would cover the data gathering skills, information processing skills, networking and collaborative skills .

TPACK framework has been the basis for assessment and investigations on Teachers' pedagogical use of Technology in actual class settings (Koehler and Mishra,2008; Mishra and Koehler,2006).Koehler and Mishra have identified 3 independent components of Knowledge related to Technology, Pedagogy and Content TK,CK,PK: 3 interrelated - Technology and content(TCK),Technology and Pedagogy (TPK) and Pedagogical content (PCK) and one integrated components -TPCK. This study attempts to evaluate the University based pre service teacher education program with regard to its compatibility with TPACK framework and acquisition of 
skills with regard to teaching using technology. The effectiveness of the course was assessed by a Pre service Teachers TPACK assessment inventory adapted from the survey of Teacher's knowledge of teaching and technology (Schmidt et al.,2009) which comprised of an achievement test in Science which assessed pre service teachers attainment of science related concepts based on School level Science. The inventory comprised of a list of questions which pertain to the 7 dimensions as identified by the TPCK framework viz., The abbreviations and explanations are the same used by Mishra and Kohler( 2006).

A one group pre-test - post test design was adopted for the study. A pre test was conducted on the first week for assessment of techno pedagogical skill. Before commencement of each module spread over 12 weeks, Pre tests was conducted. Each module in the course was aligned to one component of TPCK viz., CK, TK, PK, TCK, PCK, TPK and TPCK. Thus, 7 sets of mean scores were obtained for the 7 component based modules. After completion of each module a post test was conducted for measuring the 7 components. TPIS score was obtained from performance based assessment of teaching from observation schedules framed for the purpose. The assessment of teaching was done in the final week. Details in table 2

\section{Validity and Reliability of the tools}

The validity of the tools viz, TPACK inventory and TPIS portfolio were estimated by construct and face validity. Construct validity was estimated based on comparison with other tools developed for the same viz., survey of Teacher's knowledge of teaching and technology (Schmidt et al.,2009) and TPACK based Technology Integration Assessment Rubric (Harris et al.,2010). The tools' face validity was ensured by feedback from Teacher educators who rated the inventory with regard to select criteria such as suitability, feasibility and practicability. Reliability was ensured by student assessments done on triangulation of data - participant assessment, peer assessment and teacher assessment

\subsubsection{Findings of the study}

( Table 3)

The reliability of each pre test score for each component was estimated using Critical Ratios. An independentsamples t-test was conducted to compare Pre test and Post test scores. Details from Table 1 revealed that there was significant difference between mean scores of pre-test and post test achievement with reference to all the components for which interventions were conducted by means of content delivery, instructional design and performance assessment.

The results revealed significant difference in the scores for all dimensions of TPCK with the highest mean score for TPK $(\mathrm{M} 1=5.048, \mathrm{M} 2-15.904 ; \mathrm{SD} 1=2.42, \mathrm{SD} 2=1.84 ;$ Critical ratio- 15.95$)$.

The post test TCK scores revealed to be significantly different from the pre test scores which testifies the effectiveness of the technology enabled instructional strategy (M1=8.48,M2-18.38;SD1= 3.52,SD2=1.1.36; Critical ratio- 11.73). There was significant difference in the scores for PCK $(\mathrm{M} 1=6.38, \mathrm{M} 2-$ 18.57; $\mathrm{SD} 1=3.5, \mathrm{SD} 2=2.38$; Critical ratio- 12.88). Studies on TPACK have revealed that PCK could be enhanced through adequate instructional practices that provides learning opportunities for gaining familiarity and acquiring knowledge of pedagogical concepts. The Theoretical basis of teaching, means and techniques of information delivery contribute to building confidence and pedagogical competency of teachers ( Harris et al ; 2010,Jang 2010,Polly et al, 2010). The study also revealed that aspects related to PCK are better learned by internalizing the principles and facts of Pedagogy (Akkoc 2011,Wu et al 2008)

The Post test scores for TPCK (M1=49.33,M2-105.81,SD1=8.13,SD2=7.64;Critical ratio- 22.64) differed significantly from the pre test scores which testifies to the effectiveness of the TPCK instructional strategy. Similar results were observed for TPIS scores $(\mathrm{M} 1=6.19, \mathrm{M} 2-16.19, \mathrm{SD} 1=2.66, \mathrm{SD} 2=3.19$; Critical ratio -10.21$)$. It was observed that the pre service teachers displayed greater pedagogical skills and displayed greater confidence in pedagogical use of technology after the TPCK intervention. This is substantiated by previous studies (Figg \& Jaipal-Jamani, 2013; Jaipal-Jamani \& Figg, 2015,Glazer et al. (2009),Hughes, 2005; Hung \& Yeh, 2013; Glazer, Hannafin, \& Song, 2005, Angeli \& Valanides, 2009; Figg \& Jaipal, 2012).

Comparison of frequency distribution of mean gain scores for various sub samples based on Gender and Year of study:

The comparison of biconceptual domains of TPCK viz TCK, PCK ,TPK and consolidated scores viz., TPCK and Acquisition of skills viz., TPIS scores were compared for the sub samples based on Gender and Year of study. The mean gain scores viz., difference between the mean Pre-test and mean post test scores were categorized into the categories High, Average and Low levels. Those whose mean gain scores fall between M(Mean) - S.D (Standard Deviation) of the distribution and M+S.D were categorized as Average and those whose mean gain scores fall below M-S.D were categorized as low . The high level were those whose mean gain scores fell above M+S.D scores. 


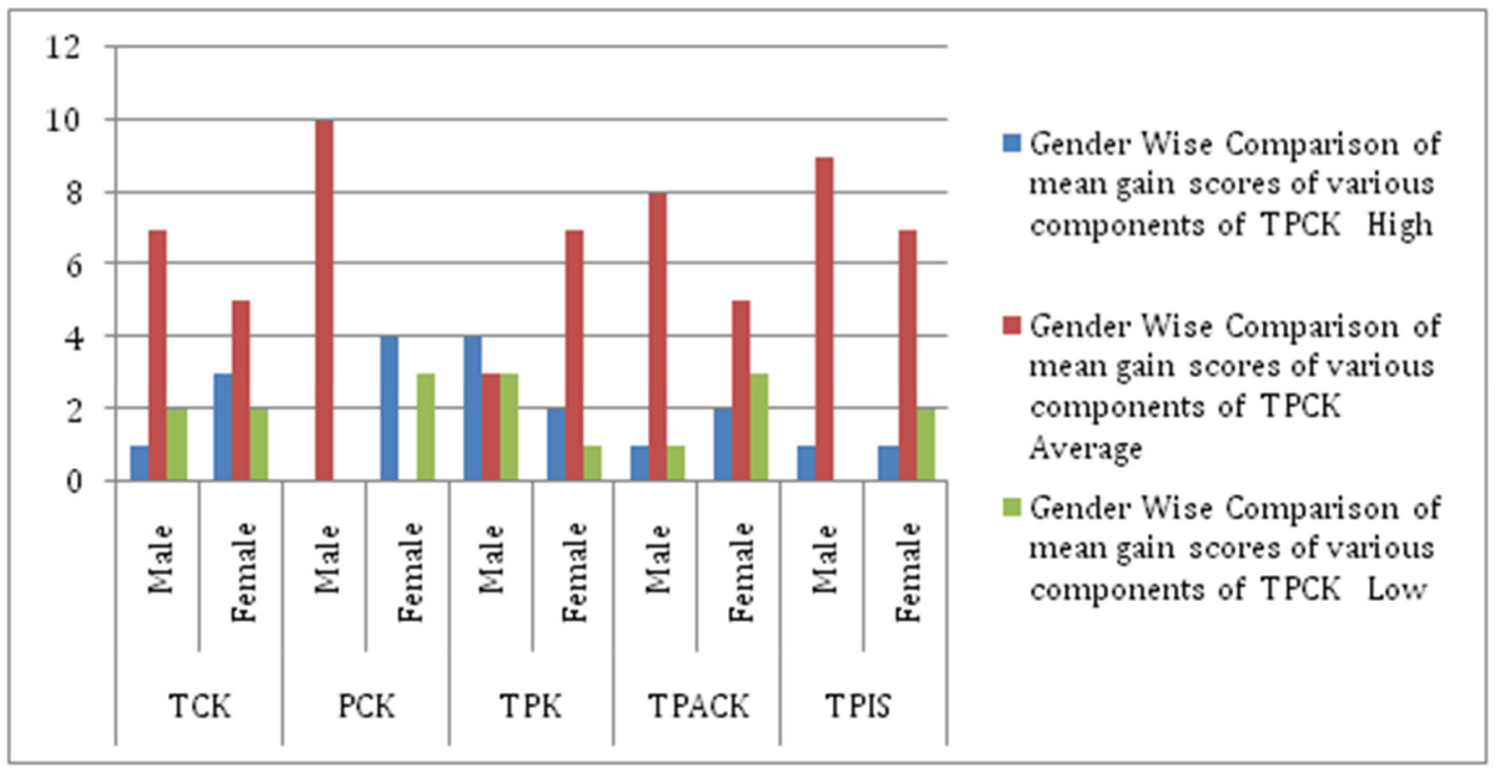

Figure 1: Gender wise comparison of mean gain scores of various components of TPCK

The results in Figure 1 revealed that greater number of females scored higher than males in the attainment of concepts related to PCK. The results reflect that males exhibited greater capability towards incorporation of application of technology and pedagogical use of technology than females as was testified from the results that revealed that the frequency of males who score high mean gain score of males from the comparison of mean gain scores for TPIS

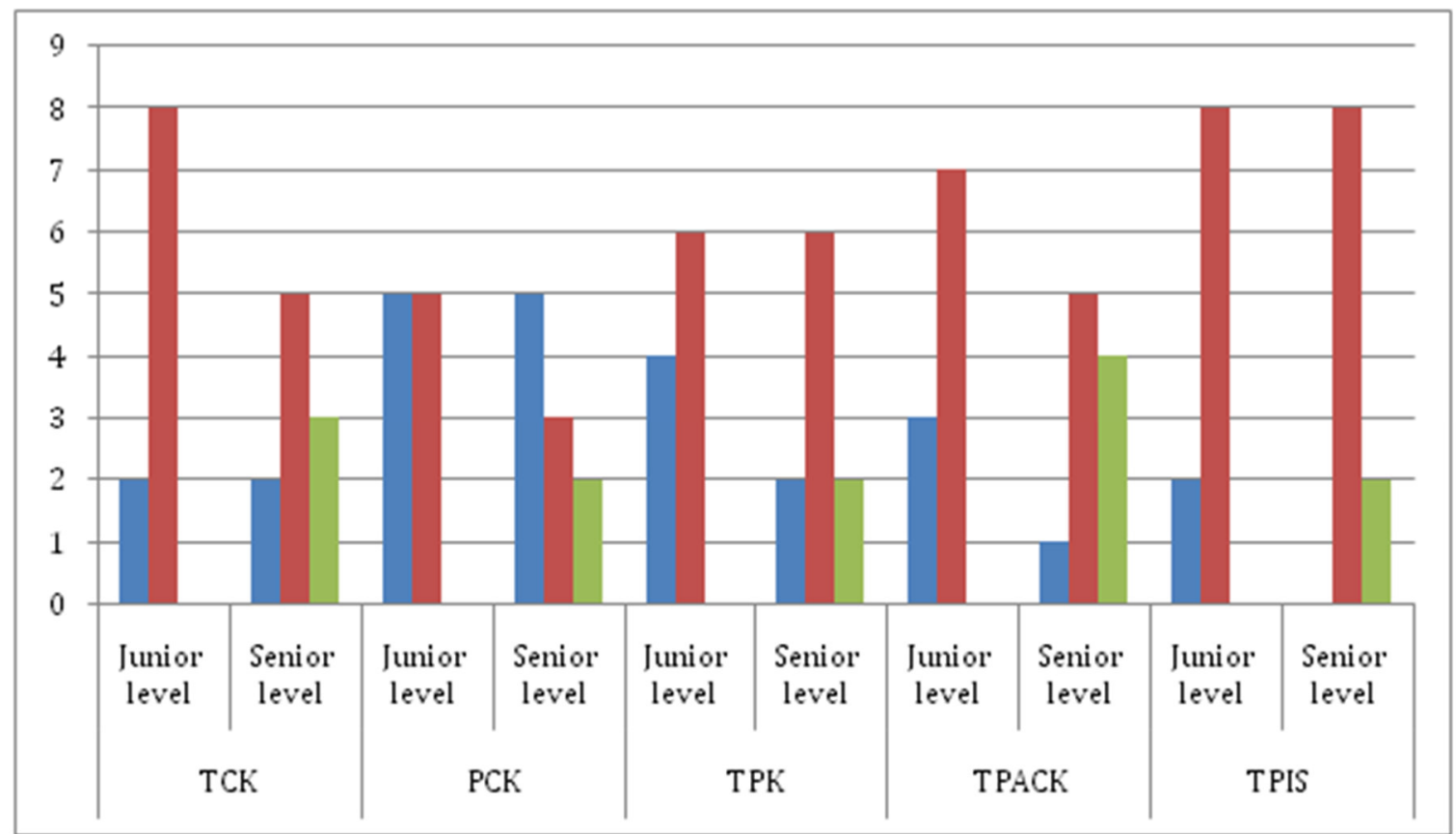

Figure 2: Year enrolled -wise comparison of mean gain scores of various components of TPCK

The results in Figure 2 revealed that greater number of senior level students still scored low in the various dual components of TPCK than the junior level students. This may be due to the fact that the technology competency and pedagogical aptitude of junior students were influenced more by the TPCK intervention than the senior level students. It is also likely that the junior year students had the pre requisites for the course than the senior level students.

\subsubsection{Discussion of results}

The results revealed that TPCK contributed to the enhancement of all components of TPCK viz, TK, PK, CK, TPK, TCK, PCK. However, the intervention using the components of TPCK helped to enhance the conceptual learning with regard to the component which was focused upon. The least gain score was with reference to the component Technology Knowledge and the highest gain was with reference to Technology Pedagogical knowledge. Similar studies on TPCK have revealed that TK could be enhanced through adequate instructional 
practices that enables opportunities for handling technology equipments, familiarity of digital resources, digital communication and online peer and community mediated delivery systems (Koh and Divahavan,2011; Harris et al,2010;Hofer and Swan,2008;Lambert and Snowey 2001; Robin,2008)

Earlier studies have revealed that TPCK based instruction can enhance CK through appropriate instructional practices and information delivery mechanisms ( Angeli and Valanides 2005; 2009).

These are mainly subjects with which the students have graduated and have acquired foundational bases of the subjects. During preservice training, CK involves gaining knowledge and understanding of concepts and helps to refresh one's concepts from the learner perspectives.

Studies have also reported that TPCK have revealed that TCK could be enhanced through adequate instructional practices that provides learning opportunities for making use of the educational potential of technology which comprise of information collection and organization using Digital tools. The study also revealed that concepts related to TCK are better understood, internalized and practices, when these become mandatory instructional practices in a teacher education curriculum. Technology enabled teacher education programs are excellent avenues whereby the foundations for TCK is imbibed during the preparatory pre service phase of becoming a teacher. During preservice training, TCK involves gaining knowledge and understanding of concepts related to Web 2.0, online tools and social media are introduced and understood. It has been reported that TPCK strategy enhances the constructs pertaining to TCK which is further supplemented with appropriate instructional practices and information delivery mechanisms (Akkoc,2011,Bowers and Stephens,2011; Groth et al 2009; Guerrins,2010). TPK could be enhanced through adequate instructional practices that provides opportunities for making use of the teaching potentials of technology which comprise of information collection, organization and delivery of instruction. Skills related to TPK are better equipped when hands on activities and direct learning experiences are provided during the pre service sessions itself.\{Khan (2011),Doering and Veletsianos (2008),Schul (2010a; 2010b). Cognitive outcomes of knowledge pertaining to Technology, Pedagogy and applied concepts related to Pedagogical skills required for optimal Technology use are enhanced through TPACK approaches ((Hammond, T. C. \& Manfra, M. M., 2009; Archambault,2011; Haciomeroglu et al.,2011,Chai et al (2013), Kontkanen, S. (2018).

The comparison of mean gain scores revealed differential influence of the intervention on the sub samples based on categories selected.

The results, hence highlight the relevance of a technology enabled learning environment and technology empowered pedagogies towards building the competence of the pre service teachers in use of technology for teaching. The skill acquisition with regard to pedagogical use of technology was seen to have enhanced as is revealed by the significant test of significance for (TPIS) score .

\subsection{Conclusion}

The TPCK framework offers a frame of reference to teachers as to the modalities that may be followed and the strategies that may be deployed for exploiting the potential of technology for pedagogical use. The fact that acquiring information of all TPCK components has contributed towards acquisition and transference of skills renders a positive feedback to the curriculum transaction conceived and implemented. The study again fortifies and advocates for such similar practices to build the teaching technique competencies of pre service teachers in relevant use of technology for teaching and learning.

The TPCK strategy can be considered as an excellent techno pedagogical tool for inculcating pre service teachers with skills in creativity and resourcefulness so as to enable capability in optimizing the digital resources and technologies for meaningful, relevant and engaged learning

\section{References}

1. Abbitt, J T .(2014) Measuring Technological Pedagogical Content Knowledge in Pre Service Teacher Education, A Review of Current Methods and Instruments,

2. Agustin, R. R., liliasari, S., Sinaga, P., \& Rochintaniawati, D. (2019). Assessing pre-service science teachers' technological pedagogical content knowledge (TPACK) on kinematics, plant tissue and daily life material. Journal of Physics: Conference Series, 1157(2), 1-5. https://doi.org/10.1088/1742-6596/1157/2/022013

3. Akkoc, H. (2011). Investigating the development of prospective mathematics teachers' technological pedagogical content knowledge with regard to student difficulties: The case of radian concept. Research in Mathematics Education, 13, 75-76. doi:10.1080/ 14794802.2011.550729

4. Angeli, C., \& Valanides, N. (2005). Preservice elementary teachers as information and communication technology designers: An instructional systems design model based on an expanded view of pedagogical content knowledge. Journal of Computer Assisted Learning, 21(4), 292-302.

5. Angeli, C., \& Valanides, N. (2009). Epistemological and methodological issues for the conceptualization, development, and assessment of ICT-TPCK: Advances in Technological Pedagogical Content Knowledge (TPCK). Computers \& Education, 52(1),154-168. 
6. Archambault, L. \& Carlson, D.L. (2011). Poetry in Motion: Using TPACK and Voice Thread to Prepare 21st Century English Teachers. In Proceedings of Society for Information Technology \& Teacher Education International Conference 2011 (pp. 4265-4272). Chesapeake, VA: Association for the Advancement of Computers in Education.

7. Archambault, L. (2016). Exploring the use of qualitative methods to examine TPACK. In M. Herring, M. Koehler, \& P. Mishra (Eds.), Handbook of technological pedagogical content knowledge for educators (2nd ed., pp. 65-86). New York, NY: Routledge

8. Archambault, L. M., \& Barnett, J. H. (2010). Revisiting technological pedagogical content knowledge: Exploring the TPACK framework. Computers \& Education, 55(4), 1656-1662. doi:10.1016/j.compedu.2010.07.009

9. Beck, J. A., \& Wynn, H. C. (1998). Technology in teacher education: Progress along the continuum. (ERIC Document Reproduction No. ED 424 212).

10. Becker, J. H., \& Riel, M. M. (2001). Teacher professional engagement and constructivist compatible computer use, report no. 7, Teaching, Learning, and Computing Project [Online], Available: http://www.crito.uci.edu/tlc/findings/report_7

11. Bos, B. (2011). Professional development for elementary teachers using TPACK. Contemporary Issues in Technology and Teacher Education,11(2).Retrieved from Technology in Education 149 http://www.citejournal.org/vol11/iss2/mathematics/article1.c fm

12. Bowers, J. S., Stephens, B. (2011). Using technology to explore mathematical relationships: A framework for orienting mathematics courses for prospective teachers. Journal of Mathematics Teacher Education,14(4), 285-304.

13. Cavanagh, R. F., \& Koehler, M. J. (2013). A turn toward specifying validity criteria in the measurement of technological pedagogical content knowledge (TPACK). Journal of Research on Technology in Education, 46(2), 129-148. https://doi.org/10.1080/15391523.2013.10782616

14. Chai, C S, Hwee, J., Koh, L., \& Tsai, C.-C. (2010). Facilitating preservice teachers' development of Technological, Pedagogical, and Content Knowledge (TPACK). Educational Technology \& Society, 13(1), 63-73. Retrieved from http://www.ifets.info/

15. Chai, C. S., Koh, J. H. L., \& Tsai, C. C. (2011). Exploring the factor structure of the constructs of Technological, Pedagogical, Content Knowledge (TPACK). The Asian Pacific Education Researcher, 20, 595-603. doi:10.1080/1359866x.2014.941280

16. Chai, C. S., Koh, J. H. L., \& Tsai, C. C. (2011). Exploring the factor structure of the constructs of Technological, Pedagogical, Content Knowledge (TPACK). The Asian Pacific Education Researcher, 20, 595-603. doi:10.1080/1359866x.2014.941280

17. Chai, C. S., Koh, J. H. L., \& Tsai, C.-C. (2016). A review of the quantitative measures of technological pedagogical content knowledge (TPACK). In M. Herring, M. Koehler, \& P. Mishra (Eds.), Handbook of technological pedagogical content knowledge for educators (2nd ed., pp. 87-106). New York, NY: Routledge

18. Chai, C.-S., Koh, J. H.-L., \& Tsai, C.-C. (2013). A Review of Technological Pedagogical Content Knowledge. Educational Technology \& Society, 16 (2), 31-51.

19. Cherner, T., \& Curry, K. (2017). Enhancement or transformation? A case study of preservice teachers' use of instructional technology. Contemporary Issues in Technology and Teacher Education, 17(2). Retrieved from $\mathrm{http} / /$ www.citejournal.org/volume-17/issue-2-17/current-practice/enhancement-or-transformation-a-casestudy-of-preservice-teachers-use-of-instructional-technology

20. de Oliveira, J. M. ; ECHENIQUE, Eliana E. G; CRUZ, OSCAR D. C.; GELIZ, Ferley R. Games, gaming and education. The New Educational Review. 22 (3-4), 2010. 129-143.

21. de Olviera, J. (2010). Pre-service teacher education enriched by technology-supported learning environments: A learning technology by design approach. Journal of Literacy \& Technology, 11(1), 89-109.

22. Doering, A., \& Veletsianos, G. (2007). An investigation of the use of real-time, authentic geospatial data in the K-12 classroom. Journal of Geography, 106, 217-225. doi:10.1080/00221340701845219

23. Duhaney, devon C .2001. Teacher education: preparing teachers to integrate technology. International Journal of Instructional Media 28 no1 2001 WN: 0100102715004 The H.W. Wilson Company

24. Figg, C., \& Jaipal-Jamani, K. (2013). Transforming classroom practice: Technology professional development that works! Teaching \& Learning, 8(1), 87-98. Retrieved from http://brock.scholarsportal.info/journals/teachingandlearning/home/article/view/431/384

25. Glazer, E., Hannafin, M. J., \& Song, L. (2005). Promoting technology integration through collaborative apprenticeship. Educational Technology Research and Development, 53(4), 57-67.

26. Glazer, E., Hannafin, M.J., Polly, D., \& Rich, P. (2009). Factors and interactions influencing technology integration during situated professional development in an elementary school. Computers in the School, 26, 21-39.

27. Groth, R., Spickler, D., Bergner, J., \& Bardzell, M. (2009). A qualitative approach to assessing technological 
pedagogical content knowledge. Contemporary Issues in Technology and Teacher Education, 9, 392-411. Retrieved from http://www. citejournal.org/vol15/iss1/

28. Guerrero, S. (2010). Technological pedagogical content knowledge in the mathematics classroom. Journal of Digital Learning in Teacher Education, 26(4), 132-139.

29. Haciomeroglu, E.S., Bu, L., Schoen, R.C., \& Hohenwarter, M. (2011). Prospective teachers' experiences in developing lessons with dynamic mathematics software. International Journal for Technology in Mathematics Education, 18 (2), 71-82.

30. Hammond, T. C., \& Manfra, M. (2009a). Digital history with student-created multimedia: Understanding student perceptions. Social Studies Research \& Practice, 4(3), 139-150.

31. Hammond, T. C., \& Manfra, M. (2009b). Giving, prompting, making: Aligning technology and pedagogy within TPACK for social studies instruction. Contemporary Issues in Technology and Teacher Education (CITE Journal), 9(2), 160-185.49

32. Hammond, T.C., \& Manfra, M.M. (2009). Giving, prompting, making: Aligning technology and pedagogy within TPACK for social studies instruction. Contemporary Issues in Technology and Teacher Education, 9(2), 160-185.

33. Harris, J. (2016). Inservice teachers' TPACK development: Trends, models, and trajectories. In M.Herring, M. Koehler, \& P. Mishra (Eds.),Handbook of technological pedagogical content knowledge for educators(2nded., pp. 191205). New York, NY: Routledge

34. Harris, J. B., \& Hofer, M. J. (2011). Technological pedagogical content knowledge (TPACK) in action: A descriptive study of secondary teachers' curriculum-based, technology related instructional planning. Journal of Research on Technology in Education, 43, 211. doi:10.1080/15391523.2011.10782570

35. Harris, J. B., Hofer, M., Schmidt, D. A., Blanchard, M.R., Young, C.Y., Grandgenett, N. F., \& Van Olphen, M. (2010). "Grounded" technology integration: Instructional planning using curriculum-based activity type taxonomies. Journal of Technology and Teacher Education, 18(4), 573-605.

36. Harris, J., Phillips, M., Koehler, M. \& Rosenberg, J. (2017). TPCK/TPACK research and development: Past, present, and future directions. Australasian Journal of Educational Technology, 33(3), i-viii. https://doi.org/10.14742/ajet.3907

37. Harris, J.S., Grandgenett, N., \& Hofer, M. (2012). Using Structured Interviews to Assess Experienced Teachers' TPACK.

38. Hofer, M., \& Swan, K. O. (2008). Technological pedagogical content knowledge in action: A case study of a middle school digital documentary project. Journal of Research on Computing in Education, 41, 179-200. doi:10.1080/15391523.2008.10782528

39. Hughes, J. (2005). The role of teacher knowledge and learning experiences in forming technology-integrated pedagogy. Journal of Technology and Teacher Education, 13(2), 227-302.

40. Hung, H. T., \& Yeh, H. C. (2013). Forming a change environment to encourage professional development through a teacher study group. Teaching and Teacher Education, 36, 153-165.

41. Jaipal, K., \& Figg, C. (2010). Unpacking the "Total Package": Emergent TPACK characteristics from a study of preservice teachers teaching with technology. Journal of Technology and Teacher Education, 18, 415-441. Retrieved from http://www.editlib. org/j/JTATE/

42. Jang, S.-J. (2010). Integrating the interactive whiteboard and peer coaching to develop the TPACK of secondary science teachers. Computers \& Education, 55, 1744-1751. doi:10.1016/j.compedu.2010.07.020

43. Jonassen, D., Howland, J., Marra, R., \& Crismond, D. (2008). Meaningful learning with technology (3rd ed.). Upper Saddle River,NJ: Pearson.

44. K Wetzel, R Zambo, R Buss, N Arbaugh.1996. Innovations in integrating technology into student teaching experiences- Journal of Research on Computing in Education, Rout ledge.

45. Khan, S. (2011). New pedagogies on teaching science with computer simulations. Journal of Science Education \& Technology,20(3), 215-232. doi:10.1007/s10956-010-9247-2

46. Koehler, M. J., Mishra, P., Yahya, K. (2007). Tracing the development of teacher knowledge in a design seminar: Integrating content, pedagogy and technology. Computers \& Education, 49, 740-762. doi:10.1016/j.compedu.2005.11.012

47. Koehler, M. J., Shin, T. S., \& Mishra, P. (2012). How do we measure TPACK? Let me count the ways. In R. N. Ronau, C. R. Rakes \& M. L. Niess (Eds.), Educational technology, teacher knowledge, and classroom impact: A research handbook on frameworks and approaches (pp. 16- 31). Hershey, PA: IGI Global. https://doi.org/10.4018/978-1-60960-750-0.ch002

48. Koh, J. H., \& Divaharan, S. (2011). Developing pre-service teachers' technology integration expertise through the TPACK-developing instructional model. Journal of Educational Computing Research, 44, 35-58. doi:10.2190/ec.44.1.c

49. Kontkanen, S. (2018). Starting points of pre-service teachers' technological pedagogical content knowledge (TPACK): Introducing a proto-TPACK model (Doctoral dissertation, University of Eastern Finland, Joensuu, 
Finland). Retrieved from http://epublications.uef.fi/pub/urn_isbn_978-952-61-2808-5/index en.html

50. Kramarski, B., \& Michalsky, T. (2010). Preparing preservice teachers for self-regulated learning in the context of technological pedagogical content knowledge. Learning and Instruction, 20, 434-447. doi:10.1016/j.learninstruc.2009.05.003

51. Lee, K., Suharwoto, G., Niess, M. \& Sadri, P. (2006). Guiding Inservice Mathematics Teachers in Developing TPCK (Technology pedagogical content knowledge). In C. Crawford, R. Carlsen, K. McFerrin, J. Price, R. Weber \& D. Willis (Eds.), Proceedings of SITE 2006--Society for Information Technology \& Teacher Education International Conference (pp. 3750-3765). Orlando, Florida, USA: Association for the Advancement of Computing in Education (AACE). Retrieved September 5, 2019 from https://www.learntechlib.org/primary/p/22684/.

52. Lieberman, A., \& Miller, L. (1991). Revisiting the social realities of teaching. In A. Lieberman \& L. Miller (Eds.), Staff development for education in the 90s (pp. 72-82). New York, NY: Teachers College Press.

53. Little, J. W., \& McLaughlin, M.W. (Eds.). (1993). Teachers work: Individuals, colleagues, and contexts. New York: Teachers College Press.

54. Manfra, M., \& Hammond, T. C. (2008). Teachers' instructional choices with student-created digital documentaries: Case studies.Journal of Research on Technology in Education, 41(2), 223-245.

55. Martin, F., \& Ertzberger, J. (2013). Here and now mobile learning: An experimental study on the use of mobile technology. Computers \& Education, 68, 76-85.

56. Mishra, P., \& Koehler, M. J. (2006). Technological pedagogical content knowledge: A framework for teacher knowledge. Teachers College Record, 108(6), 1017-1054.

57. MJ Koehler, P Mishra.2008. - Handbook of technological pedagogical content knowledge (TPCK) for educators

58. Niess, M, Lee, K., Sadri, P \& Suharwoto, G., (2006) Guiding in-service mathematics teachers in developing a technology pedagogical content knowledge(TPCK).Journal of Technology and Teacher Education.

59. Niess, M. L. 2011. Investigating TPACK: Knowledge growth in teaching with technology. Journal of Educational Computing Research, 44(3), 299-317.

60. Polly, D., Mims, C., Shepherd, C. E., \& Inan, F. (2010). Evidence of impact: Transforming teacher education with preparing tomorrow's teachers to teach with technology (PT3) grants. Teaching and Teacher Education, 26, 863-870. doi:10.1016/j.tate.2009.10.024

61. Punya Mishra (2019) Considering Contextual Knowledge: The TPACK Diagram Gets an Upgrade, Journal of Digital Learning in Teacher Education, 35:2, 76-78, DOI: 10.1080/21532974.2019.1588611 To link to this article: https://doi.org/10.1080/21532974.2019.1588611

62. Schmidt, D. A., Baran, E., Thompson, A. D., Mishra, P., Koehler, M. J., \& Shin, T. S. (2009). Technological pedagogical content knowledge (TPACK): The development and validation of an assessment instrument for preservice teachers. Journal of Research on Technology in Education, 42(2), 123-149.

63. Schrum, L. (1999). Technology professional development for teachers. Educational Technology Research and Development, 47(4), 83-90.

64. Schul, J. E. (2010a). Necessity is the mother of invention: An experienced history teacher's integration of desktop documentary making. International Journal of Technology in Teaching \& Learning, 6(1), 14-32.

65. Schul, J. E. (2010b). The emergence of CHAT with TPCK: A new framework for researching the integration of desktop documentary making in history teaching and learning. THEN: Technology, Humanities, Education \& Narrative, 7, 9-25.

66. Shafer, K. G. (2008). Learning to teach with technology through an apprenticeship model. Contemporary Issues in Technology \& Teacher Education, 8(1), 27-44.

67. Tee, M., \& Lee, S. (2011). From socialization to internalization: Cultivating technological pedagogical content knowledge through problem-based learning. Australasian Journal of Educational Technology, 27(1), 89104.51

68. UNESCO. 2012. Shaping the Education of Tomorrow: 2012 Full-length Report on the UN Decade for Education for Sustainable Development authored by Arjen E.J. Wals, Wageningen University, The Netherlands, and commissioned by UNESCO.

69. Valanides, N., \& Angeli, C. (2008c). Learning and teaching about scientific models with a computer modeling tool. Computers in Human Behavior, 24, 220-233.

70. Wakefield, J., \& Smith, D. (2012). From Socrates to satellites: iPad learning in an undergraduate course. Creative Education, 3(05), 643.

71. Wetzel, K. (1996). Innovations in Integrating Technology into Student Teaching Experiences. Journal of Research on Computing in Education, 29(2), 196-214. Retrieved September 5, 2019 from https://www.learntechlib.org/p/82880/.

72. Wu, W.-H., Chen, W.-F., Wang, T.-L., Su, C.-H. (2008). Developing and evaluating a game-based software engineering educational system. International Journal of Engineering Education, 24(4), 681-688. 
73. Yang, Y.-F., \& Tsai, C.-C. (2010). Conceptions of and approaches to learning through online peer assessment, Learning and Instruction, 20 (2010) 72-83

Table 2: Description of Subject topic and Assessment tools for measuring level of TPCK and TPIS based Evaluation of course

\begin{tabular}{|c|c|c|c|}
\hline Phase of course & Content & $\begin{array}{l}\text { Domain as per } \\
\text { TPACK } \\
\text { framework }\end{array}$ & $\begin{array}{l}\text { Nature of evaluation done in the } \\
\text { subsequent week and name of } \\
\text { instrument }\end{array}$ \\
\hline Week 1 & \multicolumn{3}{|l|}{ Pre testing for TPIS1 } \\
\hline Week 2 & $\begin{array}{l}\text { Fundamental concepts in } \\
\text { Technology -Components,devices } \\
\text { and applications- Hardware and } \\
\text { software }\end{array}$ & TK & Achievement Test-AchTK1 \\
\hline Week 3 & $\begin{array}{l}\text { History of Technology - Hardware } \\
\text { and software }\end{array}$ & TK & Achievement Test -AchTK2 \\
\hline Week 4 & Pedagogical theories & PK & Assignment \\
\hline Week 5 & Pedagogical basis of Technology & TPK & seminar \\
\hline Week 6 & search engines and web sites, & TK & $\begin{array}{l}\text { awareness tests and performance } \\
\text { based assessment of skills in use of } \\
\text { IWBs }\end{array}$ \\
\hline Week 7 & $\begin{array}{l}\text { Internet - basic, HTML and web } \\
\text { pages, Interactive white boards and } \\
\text { advanced digital technologies }\end{array}$ & TK & $\begin{array}{l}\text { creation of web page and } \\
\text { programming skills displayed }\end{array}$ \\
\hline Week 8 & $\begin{array}{l}\text { Digital content resources - locating } \\
\text { and identifying appropriate content }\end{array}$ & TCK & $\begin{array}{l}\text { rating scale scores of reliability } \\
\text { accuracy suitability, feasibility and } \\
\text { practicability of selected resource } \\
\text { content for technology based } \\
\text { teaching }\end{array}$ \\
\hline Week 9 & $\begin{array}{l}\text { Digital content resources - locating } \\
\text { and identifying appropriate } \\
\text { application software - Multimedia }\end{array}$ & TCK & $\begin{array}{l}\text { rating scale measured the } \\
\text { divisibility and level of multimedia } \\
\text { content in selected resource } \\
\text { materials }\end{array}$ \\
\hline Week 10 & $\begin{array}{l}\text { Preparation of digital resources } \\
\text { materials for pedagogy }\end{array}$ & TPCK & $\begin{array}{l}\text { rating scale scores of digital } \\
\text { resource materials based on } \\
\text { introduction of the concept, } \\
\text { explanation nation of concept, }\end{array}$ \\
\hline Week 11 & $\begin{array}{l}\text { Deploying the digital resources in } \\
\text { the classroom }\end{array}$ & TPIS & $\begin{array}{l}\text { Evaluation of Teaching } \\
\text { performance- Performance based } \\
\text { assessment based on select criteria }\end{array}$ \\
\hline Week 12 & POST testing for TPIS & & \\
\hline
\end{tabular}


Table 3 Comparison of Course effectiveness with respect to learning outcomes of TPACK

\begin{tabular}{|c|c|c|c|c|c|}
\hline S1 No & Domain & $\begin{array}{l}\text { Sub } \\
\text { Samples }\end{array}$ & Mean & $\begin{array}{l}\text { Standard } \\
\text { Deviation }\end{array}$ & Critical Ratio \\
\hline 1 & Technology Knowledge & $\begin{array}{l}\text { Pre test } \\
\text { Post test }\end{array}$ & $\begin{array}{l}14.47 \\
18.38\end{array}$ & $\begin{array}{c}3.572 \\
1.36\end{array}$ & 4.58 \\
\hline 2 & Pedagogical Knowledge & $\begin{array}{l}\text { Pre test } \\
\text { Post test }\end{array}$ & $\begin{array}{l}7.71 \\
18.57\end{array}$ & $\begin{array}{l}2.31 \\
2.38\end{array}$ & 14.67 \\
\hline 3 & Content Knowledge & $\begin{array}{l}\text { Pre test } \\
\text { Post test }\end{array}$ & $\begin{array}{l}7.23 \\
15.90\end{array}$ & $\begin{array}{l}2.64 \\
1.84\end{array}$ & 12.04 \\
\hline 4 & Technology Content Knowledge & $\begin{array}{l}\text { Pre test } \\
\text { Post test }\end{array}$ & $\begin{array}{l}8.48 \\
18.4\end{array}$ & $\begin{array}{l}3.52 \\
1.36\end{array}$ & 11.73 \\
\hline 5 & $\begin{array}{l}\text { Pedagogical } \\
\text { Content Knowledge }\end{array}$ & $\begin{array}{l}\text { Pre test } \\
\text { Post test }\end{array}$ & $\begin{array}{l}6.38 \\
18.57\end{array}$ & $\begin{array}{l}3.50 \\
1.36\end{array}$ & 12.88 \\
\hline 6 & Technology Pedagogical Knowledge & $\begin{array}{l}\text { Pre test } \\
\text { Post test }\end{array}$ & $\begin{array}{l}5.048 \\
15.90\end{array}$ & $\begin{array}{l}2.42 \\
1.84\end{array}$ & 15.95 \\
\hline 7 & TPACK & $\begin{array}{l}\text { Pretest } \\
\text { Post test }\end{array}$ & $\begin{array}{l}49.33 \\
105.81\end{array}$ & $\begin{array}{l}8.13 \\
7.64\end{array}$ & 22.64 \\
\hline 8 & TPIS & $\begin{array}{l}\text { Pre test } \\
\text { Post test }\end{array}$ & $\begin{array}{l}6.90 \\
16.19\end{array}$ & $\begin{array}{l}2.66 \\
3.07\end{array}$ & $10.21 *$ \\
\hline
\end{tabular}

